\title{
Why so many apparently rare beetles in Chilean temperate rainforests?
}

\author{
¿Por qué hay tantos coleópteros presuntamente raros en los bosques templados de Chile? \\ BARRY J. RICHARDSON ${ }^{1, *}$ \& ELIZABETH T. ARIAS-BOHART ${ }^{2}$ \\ ${ }^{1}$ CSIRO Ecosystem Sciences, GPO Box 1700, Canberra, ACT 2601, Australia. \\ ${ }^{2}$ University of California, Essig Museum of Entomology, Wellman Hall no. 210, Berkley, CA 94720, California, USA \\ ${ }^{*}$ Corresponding author: barry.richardson@csiro.au
}

\begin{abstract}
Species abundance curves were calculated from data sets collected by fogging 52 trees in Nothofagus forest ( 46000 specimens) and 24 trees in Araucaria forest ( 15000 specimens) in Chile. Neither data set fitted the standard species abundance models. Like similar data sets collected from tropical forests, there were too many species represented by single specimens. The proposal that these were vagrants normally found on other tree species was not supported as, unlike tropical forests, Nothofagus forests are not diverse, often consisting of single species stands. Examination of three assumptions of the most parsimonious equilibrium models showed them to be false. Between them the observations of undersampling bias, community disequilibria and combining data from different feeding guilds with different species abundance curves are likely to be sufficient to explain the divergence of data for large speciose beetle communities from the predictions of any of the equilibrium models. Until these three factors can be fully accounted for and residual divergence detected, there is no necessity to propose further, more complex, mechanisms to explain such data sets. Estimated values of alpha and Simpson D were shown to be strongly sample size dependent, affecting their value as estimators of biological diversity.
\end{abstract}

Key words: species abundance curves, biodiversity estimation, body size and density.

\section{RESUMEN}

Se calcularon curvas de abundancia de especies a partir de datos obtenidos por medio de nebulización de 52 árboles en bosques de Nothofagus (aproximadamente 46000 ejemplares) y 24 árboles en bosques de Araucaria araucana (aproximadamente 15000 ejemplares) en Chile. Los datos obtenidos no se ajustan a los modelos estándares de abundancia de especies, al igual que los datos obtenidos de bosques tropicales, existen muchas especies representadas por ejemplares únicos.

La hipótesis de que los mencionados ejemplares únicos son erráticos y que se encuentran normalmente en otros árboles no fue aceptada, contrario a los bosques tropicales, los bosques de Nothofagus no son diversos y generalmente lo conforman una sola especie. El análisis de tres supuestos a partir de los modelos de equilibrio más parsimoniosos, demostró que dichos modelos son falsos. Entre ellos, las observaciones de muestreo afectadas por sesgo, desequilibrio de la comunidad y la combinación de datos procedentes de distintos estratos alimenticios con diferentes curvas de abundancia de especies, parecen ser suficientes para poder explicar la divergencia de los datos para las comunidades de coleópteros con alto número de especies, a partir del supuesto de cualquier modelo de equilibrio. Hasta que estos tres factores se puedan tomar en cuenta y se pueda detectar divergencia residual, no existe necesidad de proponer mecanismos más complejos para explicar dichos datos. Los valores estimados de alfa y Simson D están estrechamente correlacionados al tamaño de la muestra, lo cual afecta su valor como estimador de la diversidad biológica.

Palabras clave: curvas de abundancia de especies, estimadores de diversidad biológica, tamaño corporal y densidad.

\section{INTRODUCTION}

There is a need to develop and test the simplest possible models in ecology using the most parsimonious set of assumptions before adding further variables leading to more complex explanations of data sets (e.g., Gotelli \& Graves 1996, Hubbell 2001, Magurran
2005, Coddington et al. 2009). The need for such an approach is evident when exploring the assembly rules predicting the relative abundances of species in a community. In some cases one or more of the available models (e.g., Hubbell 2001, Magurran 2004) has been found to fit the patterns seen in field data sets. (e.g., Volkov et al. 2003, Chave 2004, Wooton 
2005). Some data sets, however, do not fit any of the models, with tropical rainforest beetle communities providing a notable example (e.g., Morse et al. 1988, Hubbell 2001). Such communities typically have a few species that are more common than any of the models predict and a very large number of rare species. The failure of any of the proposed simple models to fit the observed distribution highlights the limitations of our present understanding of community ecology and has led to more complex suggestions as to reasons for such mismatches (Sugihara 1980, Tokeshi 1996, Harte et al. 1999, Hubbell 2001, Magurran \& Henderson 2003) rather than a more critical examination of the assumptions underlying the present models or the nature of the data sets used.

The issue of excessive numbers of species represented by single specimens in samples (singletons) has been addressed by exploring the null hypothesis that the failure of such data sets to fit any of the standard models is due to bias introduced by undersampling (McGill 2003, Coddington et al. 2009). They also noted that intensity (average number of individuals per species in a sample) is commonly very low in arthropod studies (4-70 in beetle studies; Coddington et al. 2009). For their study of a tropical spider community, they estimated that a sampling intensity of 340 was needed to approach an adequate sample for estimating the shape of the species abundance curve in a local community. Further, non-parametric estimators of species numbers (ACE, ICE, Chao 1; defined in Magurran 2004) give serious underestimates of the real number when there is undersampling and that about three quarters of the species in the community need to be sampled before the confidence interval of the estimator includes the true number of species (Walther \& Morand 1998). As a consequence, if the sample size is too small then the estimates of the number of species made using ACE, ICE or Chao 1 will vary with sample size, instead on being independent of sample size.

A second possible explanation of the anomalous shape of the species abundance curve for tropical beetles would question the validity of the assumption of most models that the communities are in equilibrium. Communities in early successional stages or in some cases, stressed, have curves similar to those found for tropical beetle communities (a few very common species and a long tail of rare species e.g., Gray 1979, Kaiser et al. 2000). Possible causes of disequilibria in local communities include them being fugitive communities (with constantly changing membership (Azarbayjani et al. 1999) resulting, for example, from common species being overwhelmed by predators or parasitoids); having clumped distributions (due, for example, to the breeding structure of insect populations or the patchy distribution of resources (Longino et al. 2002)); being subjected to changing environmental conditions (for example, the effects of ecological differences between climatic conditions in different years (e.g., Azarbayjani et al. 1999); being subjected to edge effects (Ewers \& Didham 2008); or having insufficient time since establishment to have reached equilibrium (Hurtt \& Pacala 1995). Whatever the reason, the assumption that the observed species abundance curves reflect stable communities in equilibrium needs to be questioned.

The unified neutral theory and community apportionment models assume that all species in a modelled community belong to the same trophic level. A third possible explanation then of the divergence of the abundance distribution in field data from predictions challenges the assumption that all species in the community considered belong to the same trophic level and that consequently the observed curve is that of a single community rather than the sum of a series of independent, and different, species abundance curves (Hubbell 2001).

The usual, more complex, explanation of anomalous tropical beetle data is based on the observation that tropical forests contain a very diverse array of tree species. Stork (1997) proposed that the misfit of his data to models is due to the presence on a tree, at low frequency, of transient specimens of beetle species normally found on other host plant species in the highly diverse flora of tropical forest (see also Novotny \& Basset 2000, Longino et al. 2002, Magurran \& Henderson 2003).

Most studies of the community structure of highly diverse faunas are of tropical arthropod faunas, commonly beetle faunas. Our knowledge of community structures of 
temperate faunas is fragmentary (Hammond et al. 1997, Arias et al. 2008, Sobek et al. 2009). As a consequence, the analysis of a temperate beetle fauna data set collected in a similar way to earlier tropical data sets would be of interest.

This paper describes relevant attributes of such a data set which consists of the relative abundances of 938 beetle species collected by fogging 76 trees in the temperate rain forests of Chile. It explores possible explanations of community structure, by testing the three assumptions described above of the most parsimonious models and also examines the more complex explanation offered of the previously observed lack of fit of tropical rainforest beetle communities to predictions.

Assumption 1: If samples of the Chilean beetle community include a large number of rare species, this is due to undersampling

The intensity of sampling will be relatively low. As well, less than three quarters of the predicted species will have been collected and estimates of species numbers obtained using standard estimators (ACE, ICE, MMM, Chao 1; Colwell 2005) will increase with increasing intensity/sample size instead of being independent of sample size.

Assumption 2: If samples of the Chilean beetle community include a large number of rare species, this is due to community disequibria

The relatively recent re-establishment of the Chilean forests of the Andean foothills after the last glacial period (14 000 years BP), unlike the long-established coastal forests, offers one possible opportunity to detect a disequilibrium (Ashworth \& Hoganson 1993). If recovery to equilibrium is slow (Harte et al. 1999), we would expect the Andean foothill metapopulations to be less diverse and further from equilibrium than those in coastal forests that were not wiped out by glaciation.

If disequilibrium is due to the ephemeral clustering of sets of species at a particular time and location, then sampling the same location on occasions separated by several years should give a pattern where samples from the same year are more similar than samples from different years.
Assumption 3: If samples of the Chilean beetle community include a large number of rare species, this is due to species belonging to different trophic levels being treated as a single 'community'

The unified neutral theory and community apportionment models assume that all species in the community considered belong to the same trophic level. In fact, the beetles collected in the present study belong to a range of different feeding guilds and it is known that the community structures of these guilds differ (Arias et al. 2008). If the analyses described above are repeated with beetles from different feeding guilds considered separately then the apparent excess of singletons should disappear.

The presence of excessive numbers of rare beetle species in tropical forests is due to the presence of vagrants coming from other species of host trees

The structure of the temperate Chilean forests is different to that found in tropical rainforests, with only a relatively low diversity of host plants present in an area (McQuillan 1993). If Stork's explanation, that the large number of singletons in the tropical beetle community he studied is due to vagrant specimens of species living on other tree species, is true (Stork 1997), the limited number of tree species in Chilean temperate forests would result in a much smaller pool of vagrants and the beetle community would not include the large number of rare species seen in samples from tropical forests.

Singletons, on average, will have a larger body size than more common species

As well as the issue of the adequacy of the assumptions of the simpler theories, the data set offers the opportunity to explore another matter related to relative species abundance. Coddington et al. (2009) observed that the average size of species represented by singletons in their spider study was larger than that of all species sampled. This result is consistent with observations made on many groups (e.g., Lawton 1990). 


\section{METHODS}

The community structures of the coleopteran faunas found on separate trees in Chilean Araucaria and Nothofagus forests has been analysed by Arias et al. (2008). The material was collected by canopy fogging and they provide details of the collecting, sorting and identification methods used. In the present study, the sample set of 29 trees analysed in Arias et al. (2008) was increased to include material from 24 Araucaria (Araucaria araucana (Molina)) trees and 52 Nothofagus trees through the addition of data from more years.. The material was collected over summer in six years between 2001 and 2008 and was taken from forests in both the Andean foothills and the coastal ranges between the latitudes of $37^{\circ}$ and $42^{\circ} \mathrm{S}$ in Chile. The Nothofagus trees were of a combined data set from the very similar Nothofagus dombeyi (Mirb.) Blume, $N$. obliqua (Birb.) Blume, and N. nitida (Phil.) Krasser. Cluster analysis of the Jacquard Indices for these faunas showed the faunas of the different Nothofagus tree species were interspersed and there was no evidence that required them to be analysed separately in this analysis (Arias et al. (2008) and unpublished data).

Estimates of richness and diversity as number of individuals $(\mathrm{N})$, observed number of species $\left(\mathrm{S}_{\mathrm{obs}}\right)$, predicted number of species (ACE, ICE, MMM, Chao $1)$, intensity $\left(\mathrm{N} / \mathrm{S}_{\mathrm{obs}}\right)$, alpha and Simpson $\mathrm{D}$ were calculated using Estimate S (Colwell 2005). An estimate of the observed shape of the metacommunity curve was obtained by combining all the field samples (Hubbell 2001). Values for the fundamental biodiversity number $(\theta$, Hubbell 2001) and the migration rate $(\mathrm{m})$ from the metacommunity into local communities were calculated from this curve using maximum likelihood methods (TeTame, Chave \& Jabot 2006). The predicted shape of the logseries and truncated lognormal curves were calculated following Magurran (2004) and the shape predicted by neutral theory following Hubbell \& Borda de Agua (2004). Gotelli \& Colwell (2001) highlight the issue of comparing estimates developed using unequal number of individuals and data is presented for approximately equal numbers of individuals when relevant.

The size (as volume) of specimens of each species was estimated by multiplying the median length, height and width of up to (and preferably) three specimens of a species. Not all species however were measured.

\section{RESULTS}

Summaries of the basic parameters of the Nothofagus and Araucaria beetle communities studied are given in Table 1 and Fig. 1. The general attributes of the communities in the two forest types are consistent with those reported by Arias et al. (2008). The observed and predicted number of species found in the Nothofagus forest are much higher than those found in the Araucaria forest. The species accumulation curves are not approaching asymptotes (Fig. 1).
If samples of the Chilean beetle community include a large number of rare species, this is due to undersampling

Arias et al. (2008) questioned the adequacy of the predictions of total species diversity they obtained because of the variation in the predictions with sample size. With the addition of data from more samples, the predicted number of species on Araucaria for example has changed from the 168 observed and 211 predicted (Chao 1) species on ten trees in Arias et al. (2008) to 296 observed and 373 predicted on 24 trees. Examination of Fig. 1 shows that, even with the larger sample sizes, none of the predictors of the number of species have stabilised, and they continue to rise with increasing sample size. While the proportion of species predicted that were actually sampled is estimated to be approximately $80 \%$ (Table 1) and, therefore above the minimum recommended level allowing the use of the estimators (Walther \& Morand 1998), the predictions have not stabilised. The absolute number of singletons rises until the $49^{\text {th }}$ tree and then begins to drop in the Nothofagus forest, though the number of doubletons continues to increase. In the Araucaria forest the numbers continue to rise through the 24 trees sampled. The number of doubletons steadily increases with sample size in both cases. The intensity of sampling (55 and 54; Table 1) is in the high range for published studies (4-70) but below that suggested by Coddington et al. $(2009 ; 340+)$ for a tropical spider community to avoid undersampling.

If samples of the Chilean beetle community include a large number of rare species, this is due to community disequibria

The shapes of the observed curves and the fitted logseries and truncated log normal models are shown in Fig. 2. It can be seen that for neither forest type do the predicted curves fit the field data; there are always too many singletons (fit to logseries, adjacent cells below five combined; Nothofagus forest $\left[\mathrm{X}^{2}{ }_{9}=84.2 \mathrm{P}\right.$ $=0.025]$ and Araucaria forest $\left[\mathrm{X}^{2}{ }_{10}=105.7 \mathrm{P}<\right.$ $0.001])$. The observed curve is not intermediate between the logseries and lognormal curves, as is commonly observed, but more extreme. Consequently, the fit of the field data to the 
lognormal curve is much worse than that to the logseries prediction. The richness and diversity values $\left(\mathrm{S}_{\mathrm{obs}}\right.$, alpha, $\theta$ and Simpson $\left.\mathrm{D}\right)$ for the Araucaria community are much lower than those found for the Nothofagus community even when adjusted to the same number of trees (Table 1) and continue to rise as the number of samples increases. The estimates of migration rates from the metacommunities into local communities under neutral assumptions are similar.
The diversities found in coastal versus Andean foothill forests are shown in Table 2. The level of diversity in Nothofagus forests as observed species, predicted species, alpha, Simpson D and species per tree are all higher in the coastal forest. Given that the estimates are not independent of sample size (Fig. 1) the data for the larger sample in each case was reanalysed to show the average values (over fifty runs) for an approximately equal number of individuals to the smaller sample. The patterns

\section{TABLE 1}

Summary of the results for beetle communities in Nothofagus and Araucaria forests in Chile. Resumen de los resultados de comunidades de coleópteros en bosques de Nothofagus y Araucarias en Chile.

\begin{tabular}{lcc}
\hline & Nothofagus forest & Araucaria forest \\
\hline No. trees sampled & 52 & 24 \\
No. individuals (combined samples) & 46595 & 1583 \\
No. species (combined samples) & 846 & 296 \\
Observed specimens per sample (mean/tree) & 896 & 662 \\
Observed species per sample (mean/tree) & 70 & 39 \\
Observed species (for $\sim 16000$ specimens) & 543 & 296 \\
Intensity (abundance/species) & 55.1 & 53.7 \\
\% of species sampled (Sobs/Chao1) & 84 & 79 \\
Predicted no. species (ICE) & 1108 & 622 \\
Predicted no. species (ACE) & 998 & 402 \\
Predicted no. species (MMM) & 1058 & 398 \\
Predicted no. species (Jack1 \pm SD) & $1120 \pm 27$ & $452 \pm 19$ \\
Predicted no. species (Chao1 \pm SD) & $1007 \pm 27$ & $373 \pm 19$ \\
Predicted no. species (Hubbell metacommunity) & 2122 & 662 \\
No. singletons (\% of total) & $21 \%$ & $30 \%$ \\
No. singletons (0.5-1.5 individuals in Hubbell & $18.5 \%$ & 51.53 \\
metacommunity, \% of total) & 146.97 \\
Migration rate (m) & 0.00317 \\
Simpson D (for $~ 16$ 000 specimens) & 33.5 \\
Alpha (for $\sim 16$ 000 specimens) & 109.9 \\
\hline & & 24.5 \\
\hline
\end{tabular}


of results were unchanged. For the Araucaria forests, observed species, alpha, Simpson $\mathrm{D}$ and species per tree are all higher in the coastal forest, however the predicted number of species varies radically between estimators.

Examination of samples taken from the same location in the same or different years shows incomplete clustering within years (Arias et al. 2008). For the largest data set from a single location, taken at Malalcahuello on Araucaria in four separate years (Fig. 3), it can be seen that the only significant clustering present is within years. There is no evidence of the maintenance of patterns of diversity in a local community between years.

\section{Community structure will differ with trophic level}

Data sets developed by subdividing the fauna into feeding guilds (Arias et al. 2008) were analysed (Table 3; Fig. 4). It can be seen that there are significant differences between the community parameters of the different guilds but little consistency between the patterns seen in Araucaria and Nothofagus forests. The presence of higher diversity in

(A) Nothofagus forest

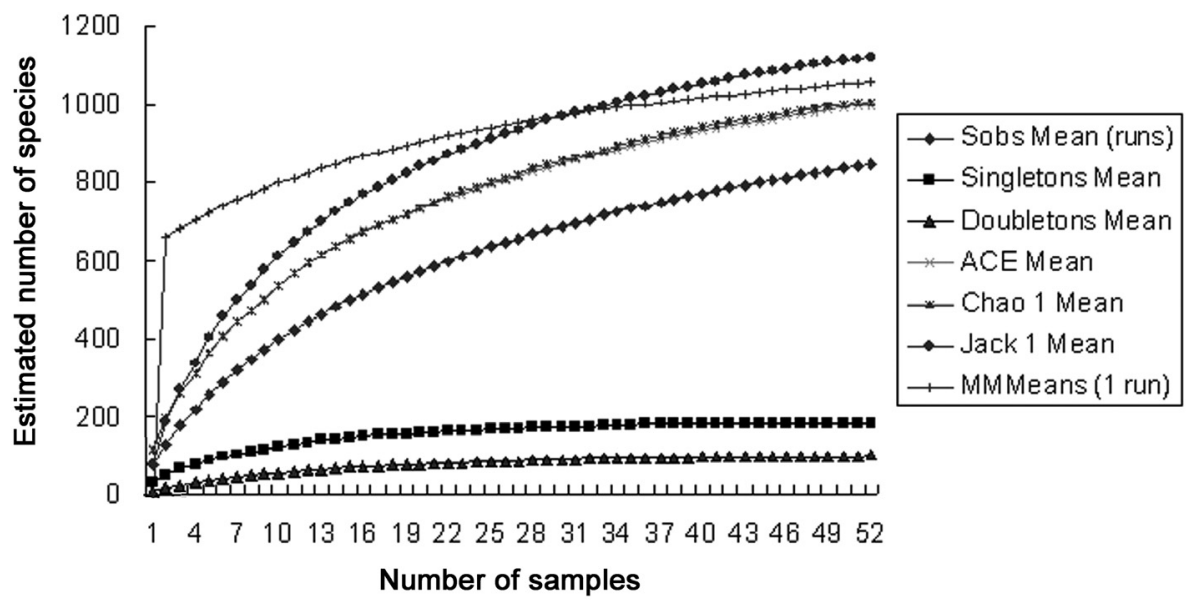

(B) Araucaria forest

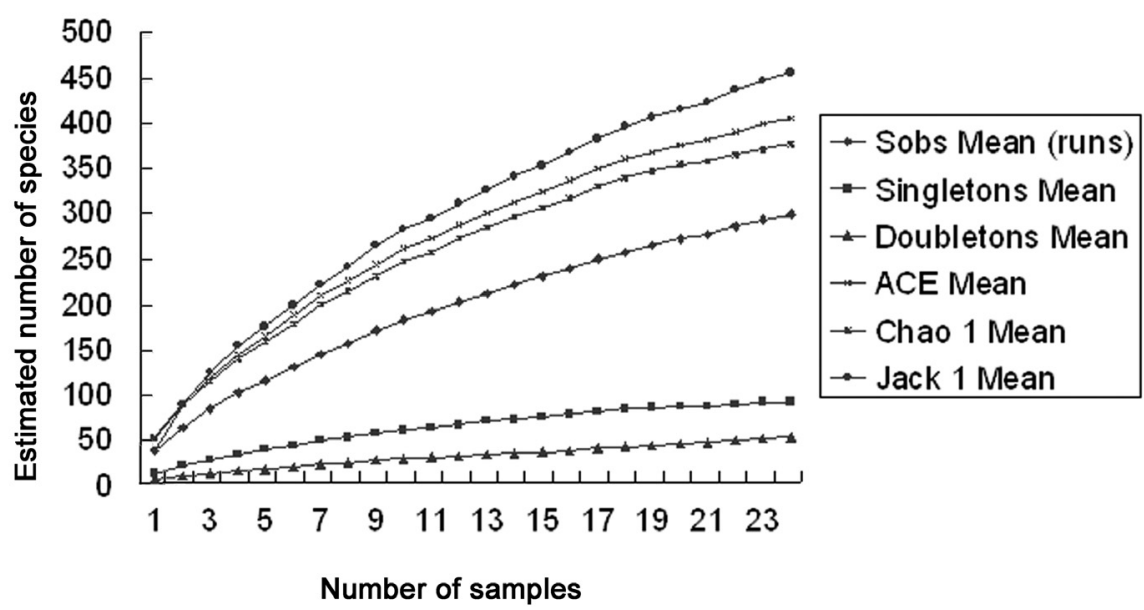

Fig. 1: Accumulation curves over samples sets for beetles collected in: (A) Nothofagus forest, (B) Araucaria forest. Curvas de acumulación de muestras de coleópteros colectados en: (A) bosques de Nothofagus, (B) bosques de Araucaria. 
the Nothofagus community than the Araucaria community is found in all guilds. Comparison of the Nothofagus data with the predictions from the fitted logseries curve showed that, when analysed in the Pearson classes 1, 2 and $3+$ by Chi squared tests (that is, testing for an excess of singletons and doubletons), there were no significant divergences from predicted for any of the feeding guilds, that is, there is not a significant excess of singletons in the sample. However the combined data was highly divergent $(\mathrm{P}<0.0001$; Fig. 2) when analysed in the same way. The data set for Araucaria forest was insufficient to allow an equivalent analysis.

The presence of excessive numbers of rare beetle species in tropical forests is due to the presence of vagrants coming from other species of host trees

Comparison of the temperate rain forest data with a set of tropical rainforest data
(Stork 1997) (Table 2; Fig. 4) shows that the species abundance curves have generally similar forms with several very common species and long tails of singletons. However the number of tropical trees analysed is much fewer and the intensity of sampling is much lower while the predicted number of species and the number of singletons is much greater. A plot of $\log \%$ singletons against $\log$ intensity (Fig. 5) shows that the point for the tropical rainforest beetle data lies just below the regression line for the Nothofagus data. If a Nothofagus forest was sampled with an intensity similar to that of the Borneo study, (intensity of 5 rather than 42 ) then an estimated $60 \%$ rather than $58 \%$ singletons found in the Borneo forest would have been observed. This is contrary to the prediction that many more singletons would be expected in a tropical forest sample than in a temperate one with little floral diversity.

TABLE 2

A comparison of the community structures of Borneo, Andean and coastal forests. 'total:' values for all trees combined, 'matching:' mean values for a subset of trees providing a sample of approximately equivalent number of individuals to that in the other area (sampling bootstrapped 50 times). *These numbers are identical entirely by chance.

Comparación de las comunidades de Borneo, cordillera de la Costa y cordillera de los Andes. 'total': valores para todos los árboles combinados, 'correspondencia' de valores promedios para submuestras de árboles equivalente al número de árboles en la otra área muestreada (muestreada 50 veces).

\begin{tabular}{lccccccc}
\hline & \multicolumn{7}{c}{ Nothofagus forest } \\
\cline { 2 - 8 } & $\begin{array}{c}\text { Borneo } \\
\text { (Stork, } \\
\end{array}$ & $\begin{array}{c}\text { Coastal } \\
\text { (total) }\end{array}$ & $\begin{array}{c}\text { Coastal } \\
\text { (matching) }\end{array}$ & Andean & $\begin{array}{c}\text { Coastal } \\
\text { (total) }\end{array}$ & $\begin{array}{c}\text { Andean } \\
\text { (matching) }\end{array}$ & Andean \\
\hline Specimens per tree & 392 & 920 & & 866 & 819 & & 567 \\
Species per tree & & 85.0 & & 53.4 & 53.2 & & 31.2 \\
No. trees & 10 & 29 & 22 & 23 & 9 & 13 & 15 \\
Total specimens & 3924 & 26669 & 20232 & 19926 & $7374^{*}$ & $7374^{*}$ & 8509 \\
Total species & 861 & 642 & 579 & 463 & 196 & 164 & 179 \\
Intensity & 4.6 & 42 & & 43 & 38 & & 48 \\
Estimated species (ACE) & & 763 & 707 & 620 & 259 & 235 & 251 \\
Estimated species (ICE) & & 876 & 853 & 749 & 381 & 414 & 455 \\
Estimated species Chao 1 \pm SD & 1781 & $779 \pm 26$ & $720 \pm 27$ & $610 \pm 28$ & $237 \pm 13$ & $228 \pm 19$ & $241 \pm 19$ \\
Alpha ( \pm SD) & 341 & $118 \pm 2$ & $112 \pm 2$ & $85 \pm 2$ & $37 \pm 1$ & $24 \pm 1$ & $32 \pm 1$ \\
Simpson D \pm SD & 70 & $30 \pm 5$ & 30 & 22 & 20 & $18 \pm 2$ & 18 \\
\hline
\end{tabular}


Singletons have, on average, a larger body size

Mean size (volume \pm SE (n)) of the singleton species measured is $174.3 \pm 51.6$ (39), of species represented by $2-5$ specimens is $72.1 \pm 23.0$ (83) and for $>5$ specimens is $34.7 \pm 14.0$ (307). Singletons are clearly, on average, larger than more common species.

\section{DISCUSSION}

The beetle diversity in Nothofagus forest is much higher than that in Araucaria forest, whether measured as observed number of species, alpha, $\theta$ or Simpson D (Table 1). The intensity (specimens per species) is similar in the two forests as is the estimated migration rates from metacommunities to local communities. On single trees, the number of species and specimens are much lower on Araucaria than Nothofagus. There is little doubt that the communities in the two forest types are significantly different.

It is possible that the different distributions are due to different attributes of the underlying trees communities. However, both Nothofagus dombeyi and

\section{(A) Nothofagus forest}

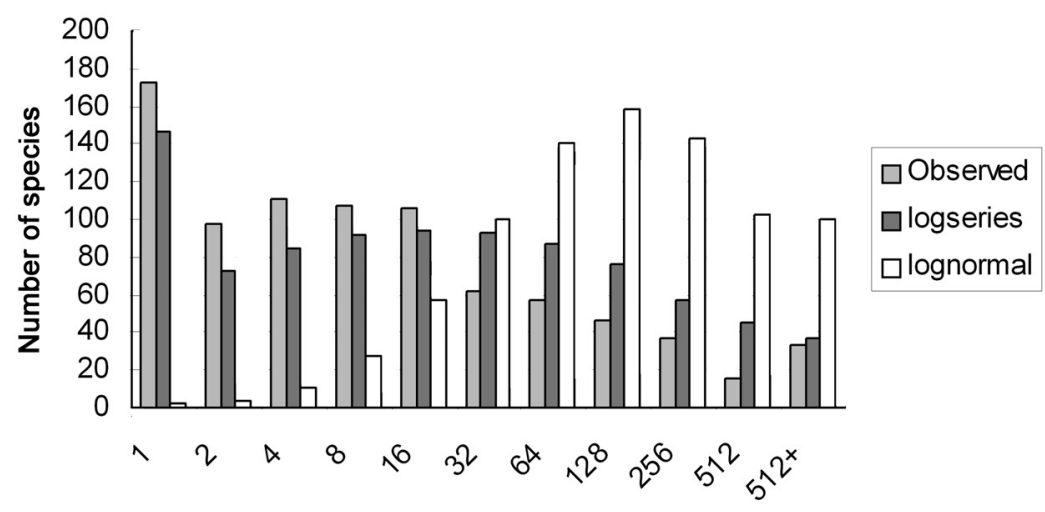

Abundance class

\section{(B) Araucaria forest}

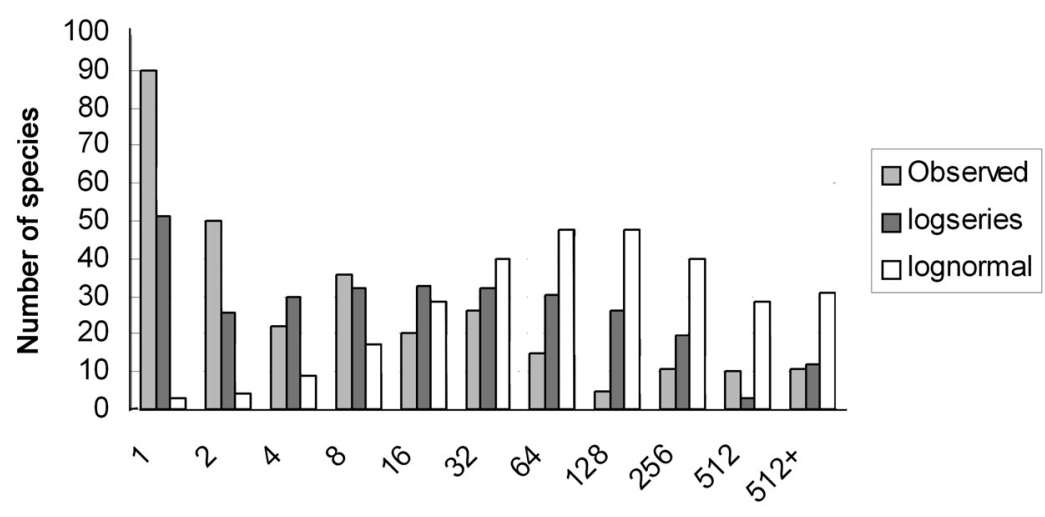

Abundance class

Fig. 2: Fit of observed beetle community data from to local community species abundance curves developed by modelling using the predicted logseries curve.

Ajuste observado de los datos de la comunidad local de coleópteros a una curva acumulada de abundancia de especies desarrolladas a partir de modelos usando la curva de logseries pronosticada. 
Araucaria araucana have comparatively high levels of allozyme polymorphism $\left(\mathrm{H}_{\mathrm{T}}=0.228\right.$ and 0.212 respectively) and geographically structured populations $\left(\mathrm{H}_{\mathrm{S}}\right.$ $=0.199$ and 0.151 respectively) (Premoli 1997, Premoli \& Kitzberger 2005, Ruiz et al. 2007). Consequently, the different community structuring observed in the beetle communities is not simply due to underlying differences in genetic diversity or the level of geographical structuring of the 'host' tree populations. It is possible that the differences are related to the fact that there are different densities of trees in the two forest types. As tree densities are estimated to be 25 trees per hectare in Araucaria forest (Smith et al. 2009) and 250 trees per hectare in Nothofagus forest (McQuillan 1993), less beetle species would be predicted on Araucaria (Hubbell 2004).

The percentage of species collected $\left(\mathrm{S}_{\mathrm{obs}}\right)$ $\mathrm{S}_{\text {pred }}$ ) should have been large enough to allow

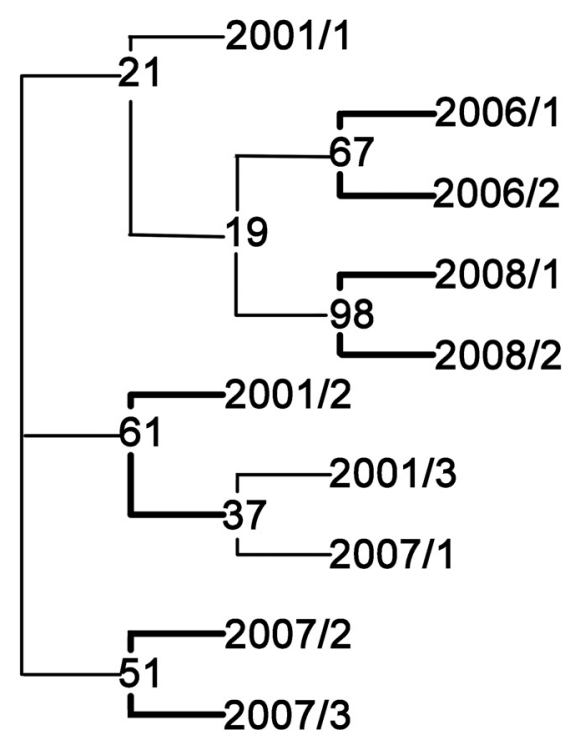

Fig. 3: Relationships between samples collected at a single location in four years. The Distance/Similarity measure is Canberra Distance linked using Saitou and Nei Neighbour Joining (year/sample number shown). The broader lines identify linkages of $>50 \%$.

Relación entre las muestras colectadas en una localidad específica durante 4 años. La medida de Distancia/Similaridad es una distancia Canberra con el uso de Saitou and Nei Neighbour Joining. Las líneas más anchas identifican las conexiones de $>50 \%$. the standard predictors to be used (Walther $\&$ Morand 1998). However, the estimations have not stabilised. The different estimators give different values for the predicted number of species, with the Hubbell estimate (Table 1) being much higher than the other estimators. It might be possible to use the estimates as the lower bound of the number of species likely to be present; however this can be very misleading. Arias et al. (2007), using the Chao 1 estimator and 12 348 specimens, give the estimated number of species in the Nothofagus forest to be 407 (362-481), while the extended study presented here gives 1007 (962-1070).

Commonly used surrogates of biological diversity (alpha, Simpson D) are also strongly affected by sample size, for example, alpha for the Nothofagus beetle community varies from 21 for a single tree sample, 60 for five trees combined, to 146 for 52 trees. Such sample size dependence makes them useless as estimators of biological diversity.

Assumptions of the more parsimonious models of community structure described above, as well as the more complex explanation offered of the previously observed lack of fit of tropical rainforest beetle communities to predictions, can now be explored.

If samples of the Chilean beetle community include a large number of rare species, this is due to undersampling

The prediction that standard estimators would increase with increasing sample size is confirmed (Fig. 1) even though the proportion sampled has reached approximately $80 \%$ (Table 1) of the predicted number of species (Fig. 1) and the estimations should have stabilised. The intensity of sampling, about 55 , is comparable to values in other large studies (listed in Coddington et al. 2009). The number of singletons rises until the $49^{\text {th }}$ tree and then begins to drop in the Nothofagus forest, though the number of doubletons continues to increase. In the Araucaria forest the numbers continues to rise through the 24 trees sampled. It is clear that even with collections from 52 trees, undersampling is a significant problem and contributes to the large number of singletons observed. 
If samples of the Chilean beetle community include a large number of rare species, this is due to community disequibria

The re-establishment of the forests of the Andean foothills after the last glacial period provides an opportunity to detect long term disequilibria. If so, we would expect the Andean foothill metapopulations to be less diverse and further from equilibrium than those in coastal forests that were not wiped out by glaciation. Table 2 shows comparisons of Andean and coastal forest faunas. It is clear that, especially in Nothofagus forests, Andean diversity is lower than coastal diversity after 14000 years. Hurtt \& Pacala (1995) showed that communities could remain in disequilibrium indefinitely when dispersal and recruitment are limited. In the present case the immigration of species from the metapopulation into a local population was estimated, under neutral theory, to be 0.003 per generation for both forest types.

If disequilibrium is due to clustering of sets of species at a particular location in a particular year, then sampling the same location in the same or different years should
Borneo

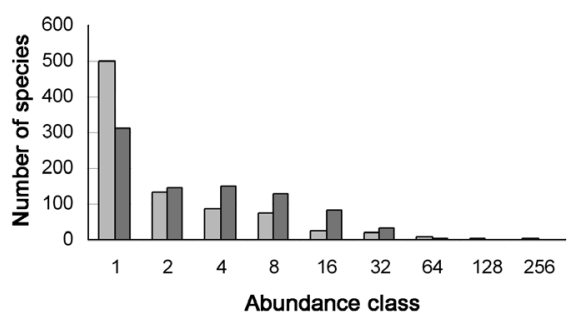

Mycetophage

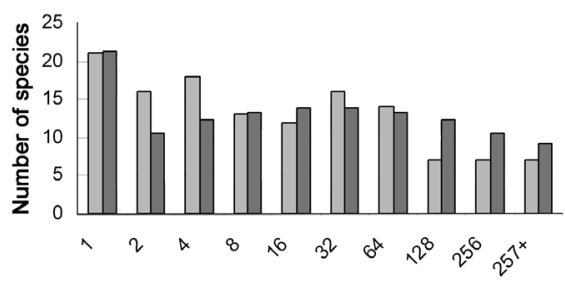

Abundance class

Phytophage

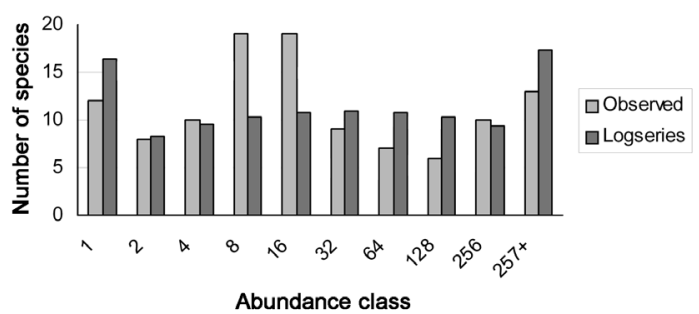

Predators

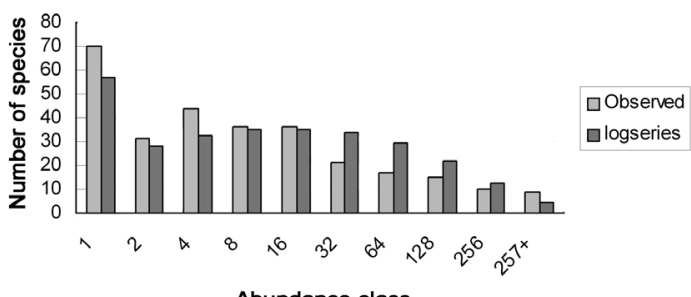

Abundance class

Scavenger

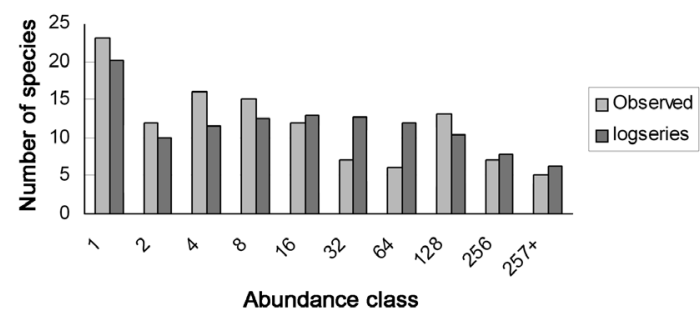

Xylophage

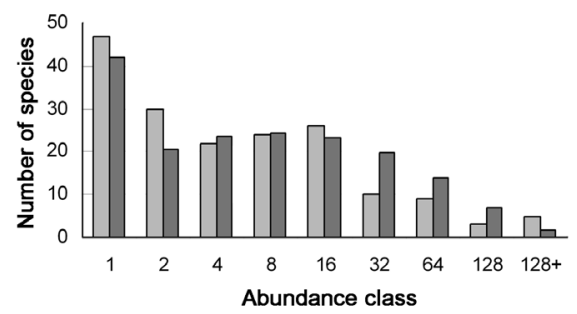

口Observed 口Logseries

Fig. 4: Fit of observed beetle community data for data for Borneo beetles from Stork (1997) and each trophic group from Nothofagus forest to species abundance curves developed by modelling using the predicted logseries curve.

Ajuste de los datos observados de la comunidad local de coleópteros (extraído de Stork 1997) y cada grupo trofico de los bosques de Nothofagus a las curva de abundancia de especies desarrolladas a partir de los modelos usando la curva logseries pronosticada. 
show clustering of samples within years. Fig. 3 shows such a pattern, with the species from samples taken in the Araucaria forest at a single location near Malalcahuello on Araucaria in four separate years, being more similar within years than between years. The type III survivorship curve typical of insects (i.e. large numbers of offspring with low average survival rates, compared to the type I pattern of few offspring and relatively high survival rates seen in terrestrial vertebrates) and a non-normal distribution of surviving offspring between parents would further exacerbate the temporal clustering effect and divergence from equilibrium in the direction observed. This is especially an issue when data sets are collected as a series of samples (here a set of specimens from a tree) rather than as independent individuals (Gotelli \& Coddington 2001).

It is clear that there is evidence of disequilibria present in the data set. There could well be other factors also causing disequilibria. Whatever the causes, however, the assumptions of the models are not met.

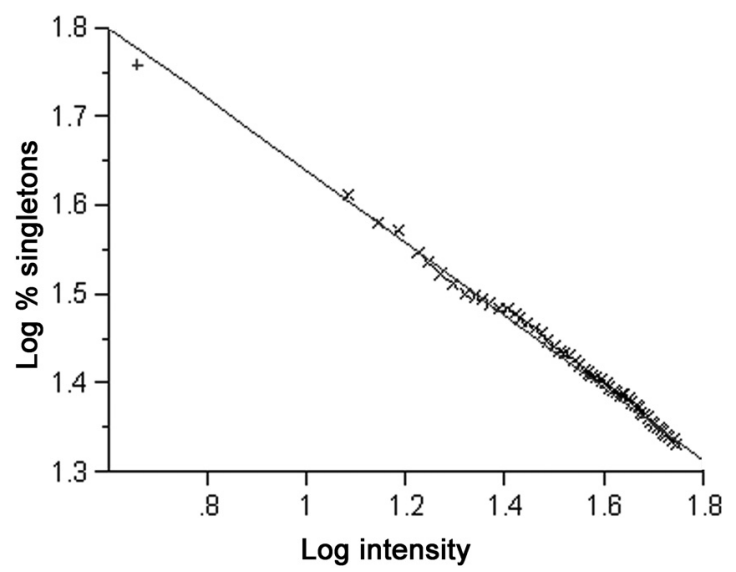

Fig. 5: Regression plot of $\log \%$ singletons against $\log$ intensity for Nothofagus forest samples (X). Also shown is the point for the tropical rainforest beetle data of Stork (1997) (+) which lies below the regression line for the Nothofagus data, not far above the line as predicted.

Plot de regresión del $\log \%$ singleton comparado con el $\log$ de intensidad para muestras de bosques de Nothofagus (X). Se muestra el punto para los coleópteros de comunidades tropicales (Stork 1997) (+) el cual está por debajo de la curva de regresión de la línea de los datos de Nothofagus, no muy lejos de la línea pronosticada.
Community structure will differ with trophic level

The unified neutral theory and community apportionment models assume that all species in the community considered belong to the same trophic level, that is, compete for the same resources (Hubbell 2001). When the analyses are repeated with beetles from different feeding guilds considered separately, the higher overall biodiversity observed in Nothofagus forest relative to Araucaria forest is found consistently in all trophic groups (Table $3)$. The relative level of diversity between trophic groups differs markedly in the two forest types and shows no consistent pattern other than the predators being the most diverse group in both cases. The null hypothesis of a single community with a single set of diversity parameters is not supported. Tests of the data for each feeding guild separately shows that there is no significant divergence from expected for the singleton and doubleton classes in any case, unlike the combined data set. The abnormal statistics for the overall beetle community is at least in part due to the combination of a series of data sets with markedly different ecological characteristics.

The presence of excessive numbers of rare beetle species in tropical forests is due to the presence of vagrants coming from other species of host trees

The parameters for Borneo rainforest beetles are summarised in Table 2 and Fig. 3. It can be seen that there are more observed and predicted species even with a much smaller sample size. It is also clear that a much higher proportion of singletons were collected. However Coddington et al. (2009) have pointed out that proportionately more singletons will be collected, the lower the intensity of sampling (here, 5 in the Borneo sample; 55 in the Chilean samples) If the value for the Borneo data is plotted on the regression of sampling intensity against the number of singletons for the Nothofagus data, to correct for the different intensities (Fig. 5), it is apparent that relatively fewer rather than the predicted more singletons were collected in Borneo. Thus there is no evidence in our comparison to support the hypothesis that tropical rainforest communities contain more singletons than temperate rainforest communities, even thought the plant 
diversity of tropical forest is much higher than that of Chilean temperate rainforest communities where Nothofagus is often found in single species stands. Consequently there is no support for the proposal that the very large number of singletons observed in rainforest beetle communities are primarily due to vagrants from other hosts.

\section{Singletons have, on average, a larger body size}

Coddington et al. (2009) observed that the average size of species represented by singletons in their spider study was larger than that of all species sampled but that this effect was due to a few very large cursorial species. A similar result was found in this study with singletons being on average more than five times the size of more common species. This raises another possible source of divergence from the assumption that the beetle fauna is acting as a single integrated community.

In summary, between them the three null hypotheses of undersampling bias, community disequilibria and feeding guilds with different patterns of diversity are likely to be sufficient to explain the divergence of data for large speciose beetle communities from the predictions of any of the equilibrium models. Until these three factors can be fully accounted for and residual divergence detected, there is no necessity to propose more complex mechanisms to explain such data.

ACKNOWLEDGEMENTS: We would like to thank all those who assisted in the fogging, sorting and identification program in Chile. Saul Cunningham, Simon Ferrier and Sharon Lawler made useful suggestions. Christine Richardson prepared the figures. We are very grateful to Dr. Richard M. Bohart for financial support. This work was also supported, in part, by the Schlinger Foundation and the National Science Foundation (Grant \#0445413).

\section{TABLE 3}

Summary of the results for beetle communities in Nothofagus and Araucaria forests in Chile subdivided into separate feeding guilds.

Resumen de los resultados de comunidades de coleópteros en bosques de Nothofagus y Araucarias en Chile, subdivididos en estratos alimenticios.

\begin{tabular}{lcccccccc}
\hline & Individuals & $\mathrm{S}_{\mathrm{obs}}$ & Intensity & $\%$ singletons & ICE & Chao $1( \pm \mathrm{SD})$ & Alpha $( \pm \mathrm{SD})$ & Simpson \\
\hline Nothofagus (52 trees): & & & & & & & \\
Mycetophage & 11571 & 134 & 86 & 16 & 162 & $146 \pm 7$ & $21 \pm 1$ & 7 \\
Phytophage & 16842 & 114 & 148 & 11 & 128 & $121 \pm 5$ & $16 \pm 1$ & 9 \\
Predator & 8833 & 289 & 31 & 24 & 391 & $362 \pm 20$ & $57 \pm 2$ & 29 \\
Scavenger & 6435 & 116 & 55 & 20 & 161 & $135 \pm 9$ & $20 \pm 1$ & 13 \\
Xylophage & 2603 & 176 & 15 & 27 & 244 & $210 \pm 12$ & $43 \pm 2$ & 21 \\
\hline \multicolumn{2}{l}{ Nothofagus (similar number of individuals): } & & & & & \\
Mycetophage & 2670 & 77 & 35 & 25 & 128 & $96 \pm 10$ & $15 \pm 1$ & 7 \\
Phytophage & 2591 & 56 & 46 & 23 & 108 & $70 \pm 8$ & $11 \pm 1$ & 77 \\
Predator & 2717 & 168 & 16 & 32 & 342 & $229 \pm 18$ & $40 \pm 2$ & 23 \\
Scavenger & 2598 & 78 & 33 & 25 & 140 & $99 \pm 10$ & $15 \pm 1$ & 12 \\
Xylophage & 2603 & 176 & 15 & 27 & 244 & $211 \pm 12$ & $43 \pm 2$ & 21 \\
\hline Araucaria $(24$ trees) & & & & & & & \\
Mycetophage & 288 & 29 & 10 & 31 & 77 & $34 \pm 4$ & $8 \pm 1$ & 12 \\
Phytophage & 6074 & 59 & 103 & 14 & 96 & $61 \pm 2$ & $9 \pm 1$ & 12 \\
Predator & 3801 & 110 & 35 & 35 & 212 & $145 \pm 13$ & $21 \pm 1$ & 6 \\
Scavenger & 508 & 49 & 10 & 33 & 106 & $60 \pm 7$ & $13 \pm 1$ & 9 \\
Xylophage & 5107 & 41 & 125 & 37 & 104 & $76 \pm 29$ & $6 \pm 1$ & 6 \\
\hline
\end{tabular}




\section{LITERATURE CITED}

ARIAS ET, BJ RICHARDSON \& M ELGUET (2008) The canopy beetle faunas of Gondwanan element trees in Chilean temperate rain forests. Journal of Biogeography 35: 914-925.

ASHWORTH AC \& JW HOGANSON (1993) The magnitude and rapidity of the climate change marking the end of the Pleistocene in the mid-latitudes of South America. Palaeogeography, Palaeoclimatology, Palaeoecology 101: 263-270.

AZARBAYJANI FF, S BURGIN \& BJ RICHARDSON (1999) Arboreal arthropod biodiversity in woodlands. II. The pattern of recovery of diversity on Melaleuca linariifolia following defaunation. Australian Journal of Ecology 24: 655-661.

CHAVE J (2004) Neutral theory and community ecology. Ecological Letters 7: 241-253.

CHAVE J \& F JABOT (2006) TeTame: Estimation of $\mathrm{q}$ and $\mathrm{m}$ by maximum likelihood in the neutral model with dispersal limitation. Version 1.1, URL: http://www.edb.ups-tlse.fr/equipe1/chave/ tetame.htm (accessed 4 May 2006).

CODDINGTON JA, IA GNARSSON, JA MILLER, M KUNTNER \& G HORMIGA (2009) Undersampling bias: The null hypothesis for singleton species in tropical arthropod surveys. Journal of Animal Ecology 78: 573-584.

COLWELL RK (2005) EstimateS: Statistical estimation of species richness and shared species from samples. Version 7.5. URL: http://purl.oclc.org/ estimates (accessed May 2010)

EWERS RM \& RK DIDHAM (2008) Pervasive impact of large-scale edge effects on a beetle community. Proceedings of the National Academy of Sciences 105: 5426-5429.

GOTELLI NJ \& GR GRAVES (1996) Null models in ecology. Smithsonian Books, Washington DC.

GOTELLI NJ \& RJ CODDINGTON (2001) Quantifying biodiversity: Procedures and pitfalls in the measurement and comparison of species richness. Ecology Letters 4: 379-391.

GRAY JS (1979) Pollution induced changes in populations. Philosphical Transactions of the Royal Society, London B 286: 545-561.

HAMMOND PM, NE STORK \& MJD BRENDELL MJD (1997) Tree-crown beetles in context: A comparison of canopy and other ecotone assembages in a lowland tropical foest in Sulawesi. In: Stork NE, JA Adis \& RK Sidham (eds) Canopy arthropods: 184-223. Chapman \& Hall, London.

HARTE J, A KINZIG \& J GREEN (1999) Self-similarity in the distribution and abundance of species. Science 284: 334-336.

HUBBELL SP (2001) The unified neutral theory of biodiversity and biogeography. Princeton University Press, Princeton.

HUBBELL SP \& L BORDA DE AGUA. (2004) The unified neutral theory of biodiversity and biogeography: Reply. Ecology 85: 3175-318.

HURTT GC \& SW PACALA (1995) The consequences of recruitment limitation. Reconciling chance, history and competitive differences between plants. Journal of Theoretical Biology 176: 1-12.

KAISER MJ, K RAMSAY, CA RICHARDSON, FE SPENCE \& AR BRAND (2000) Chronic fishing disturbance has changed shelf sea benthic community structure. Journal of Animal Ecology 69: 494-503.

LAWTON JH (1990) Species richness and population dynamics of animal assemblages. Patterns in body size: Abundance space. Philosophical Transactions of the Royal Society, London B 3330: 283-291.

LONGINO JT, J CODDINGTON \& RK COLWELL (2002) The ant fauna of a tropical rain forest: Estimating species richness three different ways. Ecology 83: 689-702.

MAGURRAN AE (2004) Measuring Biological Diversity. Blackwell Science, Oxford.

MAGURRAN AE (2005) Species abundance distributions: Pattern or process? Functional Ecology 19: 177-181.

MAGURRAN AE \& PA HENDERSON (2003) Explaining the excess of rare species in natural species abundance distributions. Nature 422: 714-716.

MCGILL BJ (2003) A test of unified neutral theory of biodiversity. Nature 422: 881-885.

MCQUILLAN PB (1993) Nothofagus (Fagaceae) and its invertebrate fauna - an overview and preliminary synthesis. Biological Journal of the Linnean Society 49: 317-354.

MORSE DR, NE STORK \& JH LAWTON (1988) Species number, species abundance and body length relationships of arboreal beetles in Bornean lowland rain forest trees. Ecological Entomology 13: 25-27.

NOVOTNY V \& Y BASSET (2000) Rare species in communities of tropical insect herbivores: Pondering the mystery of singletons. Oikos 89: 564-572.

PREMOLI AC (1997) Genetic variation in a geographically restricted and two widespread species of South American Nothofagus. Journal of Biogeography 24: 883-892.

PREMOLI AC \& T KITZBERGER (2005) Regeneration mode affects spatial genetic structure of Nothofagus dombeyi forests. Molecular Ecology 14: 2319-2329.

RUIZ E, F GONZÁLEZ, C TORRES-DÍAZ, G FUENTES, M MARDONES et al. (2007) Genetic diversity and differentiation within and among Chilean populations of Araucaria araucana (Araucariaceae) based on allozyme variability. Taxon 56: 1221-1228.

SMITH N, N VARELA \& E VIDELA (2009) Resumen ejecutivo tipo forestal araucaria. Ecología Forestal, Santiago, Chile.

SOBEK S, I STEFFAN-DEWENTER, C CHERBER \& T TSCHARNTKE (2009) Spatiotemporal changes of beetle communities across a tree diversity gradient. Diversity and Distributions 15: 660-670.

STORK NE (1997) Measuring global diversity and its decline. In: Reaka ML, DE Wilson \& EO Wilson (eds) Biodiversity II: 41-68. Joseph Henry Press, Washington D.C.

SUGIHARA G (1980) Minimal community structure: An explanation of species abundance patterns. American Naturalist 116: 770-787.

TOKESHI M (1996) Power fraction: A new explanation for species abundance patterns in species-rich assembages. Oikos 75: 543-550.

VOLKOV I, JR BANAVAR, SP HUBBELL \& A MARITAN (2003) Neutral theory and relative species abundance in ecology. Nature 424: 1035-1037. 
WALTHER BA \& S MORAND (1998) Comparative performance of species richness estimation methods. Parasitology 116: 395-405.

Associate Editor: Sergio Roig-Juñent

Received December 6, 2010; accepted August 26, 2011
WOOTTON JT (2005) Field parameterization and experimental test of the neutral theory of biodiversity. Nature 433: 309-312. 